\title{
Hydrolysis of homocysteine thiolactone results in the formation of Protein-Cys-S-S- homocysteinylation
}

Yumnam Silla ${ }^{1,2 \#}$, Swati Varshney ${ }^{1,2}$, Arjun Ray ${ }^{1,2}$, Trayambak Basak ${ }^{1,2}$, Angelo Zinellu ${ }^{3}$, Varatharajan Sabareesh ${ }^{1} \wedge$, Ciriaco Carru ${ }^{3,4}$, Shantanu Sengupta ${ }^{1,2^{*}}$

${ }^{1}$ Genomics and Molecular Medicine, CSIR-Institute of Genomics and Integrative Biology, Mathura Road, Delhi, India

${ }^{2}$ Academy of Scientific \& Innovative Research (AcSIR), New Delhi, India.

${ }^{3}$ Department of Biomedical Sciences, University of Sassari, Sassari, Italy

${ }^{4}$ Quality Control Unit, University Hospital of Sassari (AOU Sassari), Italy

*Address for Correspondence: Shantanu Sengupta, Institute of Genomics and Integrative Biology (CSIR), South campus, Mathura Road, Delhi-110025. E-mail: shantanus@igib.res.in Phone: 91-11-27666156, Fax: 91-11-27667471

Current addresses

\#Biological Sciences and Technology Division (BSTD), Biotechnology Group, CSIR-North-East Institute of Science and Technology (CSIR-NEIST), Jorhat, Assam-785006, India

This is the author manuscript accepted for publication and has undergone full peer review but has not been through the copyediting, typesetting, pagination and proofreading process, which may lead to differences between this version and the Version of Record. Please cite this article as doi: $10.1002 /$ prot.25681

This article is protected by copyright. All rights reserved. 
^Advanced Centre for Bio Separation Technology (CBST), Vellore Institute of Technology (VIT) University, Vellore, Tamil Nadu - 632 014, India.

Running title: HTL forms S-homocysteinylated proteins

Keywords: homocysteine, homocysteine thiolactone, human serum albumin, Shomocysteinylation, N-homocysteinylation, LC-ESI-MS/MS

An increased level of homocysteine, a reactive thiol amino acid, is associated with several complex disorders and is an independent risk factor for cardiovascular disease. A majority (>80\%) of circulating homocysteine is protein bound. Homocysteine exclusively binds to protein cysteine residues via thiol disulfide exchange reaction, the mechanism of which has been reported. In contrast, homocysteine thiolactone, the cyclic thioester of homocysteine, is believed to exclusively bind to the primary amine group of lysine residue leading to $\mathrm{N}$ homocysteinylation of proteins and hence studies on binding of homocysteine thiolactone to proteins thus far have only focused on N-homocysteinylation. Although it is known that homocysteine thiolactone can hydrolyze to homocysteine at physiological $\mathrm{pH}$, surprisingly the extent of S-homocysteinylation during the exposure of homocysteine thiolactone with proteins has never been looked into. In this study, we clearly show that the hydrolysis of homocysteine thiolactone is $\mathrm{pH}$ dependent and at physiological $\mathrm{pH}, 1 \mathrm{mM}$ homocysteine thiolactone is hydrolysed to $\sim 0.71 \mathrm{mM}$ homocysteine within 24 hours. Using albumin, we also show that 
incubation of HTL with albumin leads to a greater proportion of S-homocysteinylation (0.41 $\mathrm{mol} / \mathrm{mol}$ of albumin $)$ than $\mathrm{N}$-homocysteinylation $(0.14 \mathrm{~mol} / \mathrm{mol}$ of albumin $)$. Shomocysteinylation at $\mathrm{Cys}^{34}$ of HSA on treatment with homocysteine thiolactone was confirmed using LC-MS. Further, contrary to earlier reports, our results indicate that there is no cross talk between the cysteine attached to $\mathrm{Cys}^{34}$ of albumin and homocysteine attached to lysine residues.

\section{Introduction}

The thiol amino acid, homocysteine (Hcy), is formed in the ubiquitous methionine cycle. It is a key branch point intermediate of the folate pathway and the remethylation and transulfuration pathways in the methionine cycle. An elevated level of Hcy is considered to be an independent risk factor for cardiovascular disease (1) and several epidemiological studies have shown the association of homocysteine with a wide spectrum of disease conditions like neural tube defects (2), schizophrenia (3) , stroke (4), placental abnormalities (5), diabetes (6), Alzheimer’s disease (7) etc. In circulation, free reduced homocysteine accounts for only a small fraction ( 2\%) of the total homocysteine, while about $10-20 \%$ exists as low molecular weight oxidized disulfide such as homocystine and homocysteine cysteine mixed disulfides. A majority of homocysteine ( 7080\%) exists in the protein bound form through disulfide (-S-S-) linkage. Protein bound homocysteine is also a predominant form of homocysteine in homocystinuria (8-12) and various other conditions such as end stage renal disease (13-15) peripheral vascular disease (16), stroke

This article is protected by copyright. All rights reserved. 
(17), cobalamin deficiency (18), coronary artery disease (19) etc. In addition, it is generally believed that a small fraction of homocysteine is metabolically converted to homocysteine thiolactone (HTL), a cyclic form of homocysteine, by methionine t-RNA synthetase (20). Homocysteine thiolactone is believed to bind solely to the $\varepsilon$-amino group of lysine and reports suggest that this form of homocysteine (homocysteinamide) may be present in circulation albeit accounting for a small percentage of the total plasma homocysteine levels (21).

Since, a majority of the circulating homocysteine is bound to protein, one of the mechanistic hypothesis put forth to explain the cytotoxicity of homocysteine is the "molecular targeting hypothesis”. Molecular targeting of proteins by homocysteine leads to the formation of stable disulfide bonds with protein cysteine residue, known as S-homocysteinylation while formation of stable amide bonds with activated carbonyl group of HTL and primary amino group of protein lysine residue (reaction 1) is referred to as N-homocysteinylation $(22,23)$. The detailed mechanisms of both S- and N-Homocysteinylation have been proposed using human serum albumin (23-25). Albumin is the most abundant human plasma protein with concentration ranges from $3.5-5(\mathrm{~g} / \mathrm{dl})$ and constitutes about $50 \%$ of the total plasma protein (26). Albumin is a single polypeptide chain folded in three different domains which consist of 35 cysteine residues of which 34 are involved in the formation of 17 intra-chain disulfide bonds. Interestingly, albumin has a single cysteine residue at position $34\left(\mathrm{Cys}^{34}\right)$ which is not involved in the intrachain disulfide bond formation and this cysteine accounts for the bulk of free thiol in plasma (27). A majority of this cysteine $\left(\mathrm{Cys}^{34}\right)$ exists in the free reduced form (albumin-Cys ${ }^{34}-\mathrm{SH}$, 
$>65 \%$ ) while one-third of albumin-Cys ${ }^{34}$ is bound to cysteine (albumin-Cys ${ }^{34}$-S-S-Cys) and about $2 \%$ is bound to homocysteine (albumin-Cys ${ }^{34}$-S-S-Hcy) in circulation. It has been established that homocysteine binds to albumin-Cys ${ }^{34}$ through a two-step reaction (24). In the first step, homocysteine binds to the cysteine attached to $\mathrm{Cys}^{34}$ forming albumin thiolate anion and homocysteine-cysteine mixed disulfide. In the second step, albumin thiolate anion, thus formed, binds to homocysteine-cysteine mixed disulfide to primarily form Albumin bound homocysteine (Alb-Cys ${ }^{34}$-S-S-Hcy).

The mechanism of N-homocysteinylation has also been proposed and it has been shown that HTL binds to the $\varepsilon$-amino group of lysine residues exclusively forming $\mathrm{N}$-homocysteinylated albumin, Albumin-Lys-Hcy-SH (23). Further, it has also been reported that there is a cross talk between cysteine attached to $\mathrm{Cys}^{34}$ of albumin and homocysteine bound to albumin lysine residue, resulting in the formation of Albumin-Lys-Hcy-S-S-Cys (23). Interestingly, there are reports showing that HTL readily hydrolyses in vitro and in circulation undergoes enzymatic hydrolysis by paraoxonase (PON1) to form homocysteine $(22,28,29)$. If this is indeed the case, then the reaction of HTL with albumin should lead to both protein-S-homocysteinylation along with N-homocysteinylation since, if HTL hydrolyses at physiological $\mathrm{pH}$ to homocysteine, then the homocysteine formed could potentially bind to $\mathrm{Cys}^{34}-\mathrm{SH}$. However, till date, surprisingly, there are no reports showing that incubation of HTL with proteins could lead to protein-Shomocysteinylation.

This article is protected by copyright. All rights reserved. 
In this study, we not only show that S-homocysteinylation is the predominant product formed during the incubation of HTL with albumin, but also show that there is no cross talk between cysteine attached to $\mathrm{Cys}^{34}$ and homocysteine attached to lysine (N-homocysteinylation).

\section{Materials and methods}

\section{Reagents}

DL-homocysteine (Hcy), DL-Homocysteine-thiolactone (HTL), Dithiothreitol (DTT), 5,5’dithiobis-(2-nitrobenzoic acid) (DTNB or Ellman’s reagent), Ethylenediamine tetra-acetic acid (EDTA), Formic Acid, Glutathione, Iodoacetamide, L-homocystine, L-cysteine, Trizma® (Tris base), Monobromobimane, Sodium borohydride, Sodium acetate and human serum albumin were purchased from Sigma (St. Louis, MO, U.S.A.). Perchloric acid, HPLC grade acetonitrile and methanol were purchased from Fisher (Fair Lawn, NJ, U.S.A). HPLC grade acetic acid was purchased from HIMEDIA (Mumbai, India). Isoamyl alcohol was purchased from BDH laboratory (Poole, UK) and Trypsin from Promega (Madison, U.S.A). All other chemicals used in this study were of analytical grade.

\section{Determination of albumin bound homocysteine and cysteine during HTL binding to albumin}

To determine the amount of homocysteine bound to albumin by Hcy or HTL, 0.75 mM HSA in $1 \mathrm{ml}$ of $0.1 \mathrm{M}$ sodium phosphate buffer (pH-7.4) was incubated with $1 \mathrm{mM}$ of either HTL or homocysteine. The reaction mixture was incubated at $37^{\circ} \mathrm{C}$ in shaker with continuous shaking. 
From this, $0.05 \mathrm{ml}$ aliquots were withdrawn at various time points and transferred to tubes containing $0.1 \mathrm{ml}$ of $1.5 \mathrm{M}$ perchloric acid to stop the reaction by precipitating albumin. The tubes were vortexed and incubated in ice for 10 minutes. After centrifugation at 12,000 rpm for 10 minutes, the protein pellet was washed three times with $0.1 \mathrm{ml}$ of $1.5 \mathrm{M}$ perchloric acid. The washed pellet was dissolved in $0.1 \mathrm{ml}$ of $0.5 \mathrm{M}$ Tris $\left(\mathrm{pH}\right.$ 8.5) and stored at $-20^{\circ} \mathrm{C}$. Albumin bound homocysteine and cysteine was measured using high performance liquid chromatography (HPLC) equipped with fluorescence detector (30). Briefly, $0.1 \mathrm{ml}$ of the dissolved pellet was treated with $0.035 \mathrm{ml}$ of freshly prepared $1.43 \mathrm{M}$ sodium borohydride in $0.10 \mathrm{M}$ sodium hydroxide (to reduce oxidized thiols) followed by short and quick vortexing with further addition and mixing of $0.035 \mathrm{ml}$ of $1.0 \mathrm{M} \mathrm{HCl}$. To this $0.05 \mathrm{ml}$ of $7 \mathrm{mM}$ monobromobimane in $5 \mathrm{mM}$ sodium EDTA (pH-7.0) was added to conjugate the reduced thiols and the solution was incubated at $42^{\circ} \mathrm{C}$ for $12 \mathrm{~min}$. Albumin was then precipitated by the addition of $0.05 \mathrm{ml}$ of $1.5 \mathrm{M}$ perchloric acid followed by centrifugation at 12,000 rpm for 10 minutes. The supernatant $(0.10$ $\mathrm{ml}$ ) was then transferred to injector vials for automated HPLC analysis. $0.06 \mathrm{ml}$ of cold $2.0 \mathrm{M}$ Trizma was added to the vials to neutralize the acidic pH. HPLC measurements were carried out using reverse phase C18 column (5 $\mu \mathrm{M}$ particle size, 4.6 x $150 \mathrm{~mm}$, Phenomenex, USA). Standard curves were generated with known amounts of cysteine and homocysteine to calculate the concentrations of these two thiols in the reaction mixture.

\section{Binding capacity of HTL to Plasma protein}

This article is protected by copyright. All rights reserved. 
Blood collection and Plasma separation Blood samples were collected from healthy individuals $(\mathrm{n}=5)$ in vacutainer tubes (Becton-Dickinson) containing EDTA. All the individuals provided their written consent on the day of collection by filling a questionnaire on the same day when blood samples were collected from the individuals. The study was approved by institutional ethical committee following the Helsinki Declaration. Whole blood sample was collected from these individuals (after overnight fasting) and immediately put on ice for 30-45 minutes and centrifuged at $12000 \mathrm{~g}$ for 20 minutes at $40^{\circ} \mathrm{C}$. Plasma was separated and stored at $80^{\circ} \mathrm{C}$ until further use.

\section{Plasma protein bound homocysteine and cysteine}

The amount of S-homocysteinylated plasma protein was determined during HTL binding to human plasma. Plasma protein bound homocysteine and cysteine was determined as described by Togawa et al. (31). Briefly, human plasma $(1 \mathrm{ml})$ was diluted with $1 \mathrm{ml}$ of $0.1 \mathrm{M}$ sodium phosphate buffer (pH-7.4) and pre-incubated at $37^{\circ} \mathrm{C}$ for 10 minutes. To this DL- HTL (final concentration, $1 \mathrm{mM}$ ), was added and the reaction mixture was incubated at $37^{\circ} \mathrm{C}$ in a shaker. From this, $0.05 \mathrm{ml}$ aliquots were withdrawn at various time points and transferred to tubes containing $0.02 \mathrm{ml}$ of $1.5 \mathrm{M}$ perchloric acid. Following this, the method as described above for HSA was used. Plasma protein bound homocysteine and cysteine were measured using reversephase high performance liquid chromatography equipped with fluorescence detector as mentioned above.

This article is protected by copyright. All rights reserved. 


\section{Determination of homocysteine-bound lysine during HTL binding to albumin}

To determine the amount of N-homocysteinylated albumin formed during HTL binding to albumin, the free Cys ${ }^{34}$ thiol group of albumin was treated with DTT to form albumin thiolate anion and subsequently alkylated using iodoacetamide (IAA) as described below.

\section{Preparation of albumin thiolate anion (free reduced albumin $\mathrm{Cys}^{34}$ ) and albumin Cys ${ }^{34}$-S-IAA}

Albumin thiolate anion (mercaptalbumin) was prepared as described by Sogami et al., (1984)(32) with slight modification. Briefly, $50 \mathrm{mg}$ of HSA was dissolved in $1 \mathrm{ml}$ of $0.1 \mathrm{M}$ sodium phosphate buffer with $10 \mathrm{mM}$ EDTA at physiological $\mathrm{pH}$ and treated with $1 \mathrm{mM}$ dithiothreitol (DTT) at $37^{\circ} \mathrm{C}$ for 45 min to prepare albumin thiolate anion. Albumin Cys ${ }^{34}$-SIAA was prepared by completely blocking the thiol group (-SH) of free reduced albumin-Cys ${ }^{34}$ (albumin-Cys ${ }^{34}$-SH) using IAA. For this, albumin thiolate anion $(50 \mathrm{mg} / \mathrm{ml})$ was treated with 55 $\mathrm{mM}$ IAA at $37^{\circ} \mathrm{C}$ for 30 minutes in dark. Aliquots $(50 \mu \mathrm{l})$ were withdrawn at various time points $(0,15,30,45,60,90120,180,300,480$ minutes) and transferred to tubes containing $0.1 \mathrm{ml}$ of 1.5 $\mathrm{M}$ perchloric acid to stop the reaction by precipitating the protein. The tubes were then vortexed, incubated for 10 minutes on ice and centrifuged at $12000 \mathrm{rpm}$ for 10 minutes. The pellet was washed three times with 1.5 M perchloric acid to remove excess DTT and IAA , which

This article is protected by copyright. All rights reserved. 
is then dissolved in $0.1 \mathrm{ml}$ of $0.5 \mathrm{M}$ Tris (pH-8.5). The amount of free reduced thiol and addition of IAA to albumin, at the time points mentioned above, were determined using Ellman's reagent (33).

\section{Preparation of N-homocysteinylated albumin}

$\mathrm{N}$-homocysteinylated albumin was prepared by incubating HTL with IAA treated albumin (albumin-Cys ${ }^{34}$-S-IAA). After solubilizing the IAA treated albumin as mentioned above, buffer exchange was carried out with $0.1 \mathrm{M}$ sodium phosphate (pH 7.4) by ultra-filtration through 10 $\mathrm{kDa}$ cut-off membrane centricon (Millipore) at $4^{0} \mathrm{C} .1 \mathrm{mM}$ of HTL was added to the solution and the reaction mixture was incubated at $37^{0} \mathrm{C}$ in a thermo-mixture. Aliquots $(0.05 \mathrm{ml})$ were withdrawn at various time points and precipitated with $0.1 \mathrm{ml}$ of $1.5 \mathrm{M}$ perchloric acid as mentioned above, under this condition only lysine bound HTL, i.e. IAA-S-Cys ${ }^{34}$-Albumin-Lys$\mathrm{N}-\mathrm{Hcy}-\mathrm{SH}$ could be formed. However, HTL in the solution could potentially hydrolyse to homocysteine which in turn could bind to the free thiol of homocysteine attached to the lysine residue of albumin forming IAA-S-Cys ${ }^{34}$-Albumin-Lys-N-Hcy-S-S-Hcy. Thus, to determine the actual amount of homocysteine bound directly to albumin lysine residue, we first solubilized the perchloric acid precipitate and added $0.035 \mathrm{ml}$ sodium borohydride to reduce any homocysteine that may be bound to albumin-lysine bound homocysteine and the total amount of lysine bound

This article is protected by copyright. All rights reserved. 
homocysteine [albumin-Lys-N-Hcy-SH-(albumin-Cys ${ }^{34}$-S-IAA)] (product 1 and 2 in the reaction 2) was determined by using Ellman's reagent (33).

Mass spectrometric analysis of S/N-homocysteinylated albumin tryptic peptides S-homocysteinylated Albumin peptide

To confirm S-homocysteinylation during HTL binding to albumin, high resolution electrospray ionization (ESI) mass spectrometry (MS) (QTOF 5600, AB Sciex) was used. For this $750 \mu \mathrm{M}$ native albumin, and HTL treated albumin-Cys ${ }^{34}$-SH was digested using trypsin (enzyme:substrate, 1:25) overnight at $37^{\circ} \mathrm{C}$. Then, $10 \mu \mathrm{l}$ of tryptic peptides were loaded onto an Eksigent C18 nanoLC Trap column $(350 \mu \mathrm{m} \times 0.5 \mathrm{~mm})$ and desalted at a flow rate of $3 \mu \mathrm{l} / \mathrm{min}$ for 40 mins. The peptides were then resolved on an analytical column (Eksigent C18 nanoLC column $0.075 \times 150 \mathrm{~mm}$ ) with a multistep linear gradient of mobile phase A (100\% water, $0.1 \%$ formic acid) and mobile phase B (100\% ACN, $0.1 \%$ formic acid) at a flow rate of $300 \mathrm{~nL} / \mathrm{min}$. The gradient started at 5\% buffer B for $0.1 \mathrm{~min}$, with linear increase up to 30\% B at $40 \mathrm{~min}, 50 \%$ $\mathrm{B}$ at $50 \mathrm{~min}$ and $90 \% \mathrm{~B}$ at $51 \mathrm{~min}$. The gradient was maintained at $90 \% \mathrm{~B}$ for $8 \mathrm{~min}$, before reequilibration to 5\% B for 2 min. QTOF 5600 (AB Sciex) was operated in information dependent acquisition (IDA) mode with a TOF/MS survey scan ( $\mathrm{m} / \mathrm{z}$ 350-1250) and an accumulation time of 200 millisecond (ms). The MS settings were as follows: Ionspray voltage floating: $2400 \mathrm{~V}$, curtain gas: 25 , ion source gas 1: 25 , interface heater temperature: 130 , and declustering potential: $80 \mathrm{~V}$. Eighteen precursor ions per cycle were selected for fragmentation, and each

This article is protected by copyright. All rights reserved. 
MS/MS spectrum was accumulated for $100 \mathrm{~ms}(\mathrm{~m} / \mathrm{z} 100-1800)$ with a total cycle time of approximately 2.05 seconds.

\section{Data Processing and Data Analysis}

Data in the constituted MS and MS/MS spectra scan was obtained from QTOF 5600 in the form of .wiff files. These .wiff files from each experiment were submitted to ProteinPilot ${ }^{\mathrm{TM}}$ software (v.4.5 AB Sciex, Foster City, CA) to identify peptides of human serum albumin. The search parameters were as follows: trypsin as the digestion enzyme with two missed cleavages. The theoretically predicted peptide's intact mass from the protein pilot was matched to the mass of the experimentally identified peptide. LC-ESI-MS data, MS/MS spectral data (.wiff files) were imported in Peak View (v. 2.1 AB Sciex, Foster City, CA) for identification of Shomocysteinylation manually. In case of S-homocysteinylation, mass of homocysteine $\left(\mathrm{C}_{4} \mathrm{H}_{9} \mathrm{NO}_{2} \mathrm{~S}, 135 \mathrm{Da}\right)$ was added, i.e., $\Delta \mathrm{M}=+133$ Da to protein, for identification of homocysteine in the tryptic peptide.

The MS/MS data of HTL modified peptides were analyzed manually based on the theoretically calculated $\mathrm{m} / \mathrm{z}$ values of peptide fragment ions obtained from the standalone software, Peptide Fragment Ion Analyzer (34). Mass of homocysteine (+ $133 \mathrm{Da}$ ) was added to the $b$ and $y$ ions of the unmodified tryptic peptide(s) and such theoretically calculated modified $m / z$ values of $b$ and $y$ ions were then matched with the experimentally detected ESI MS/MS spectra of the tryptic peptide(s).

This article is protected by copyright. All rights reserved. 


\section{RESULTS AND DISCUSSSION}

HTL hydrolysis leads to formation of Albumin bound homocysteine through disulfide (-S-S-) linkage (S-homocysteinylation)

Homocysteinylation of proteins is gaining attention, since it is increasingly being recognized that the binding of homocysteine to proteins could potentially alter the structure and/or the function of the proteins. We had earlier shown that the binding of homocysteine to fibronectin potentially alters its ability to bind fibrin (35). Similarly there are other reports that clearly points to the modulation of protein function on homocysteinylation (36). Using molecular dynamic simulation, we have recently shown that homocysteine could also potentially alter the structure of proteins granzyme B and junctional adhesion molecule 1(36, 37). Binding of homocysteine to proteins via thiol disulfide exchange reaction has been documented (24). However, with the discovery that homocysteine could exist in its thiolactone form led to the hypothesis of proteinlysine-N-homocysteinylation which was later elegantly demonstrated by Jakubowski and his colleagues. The concentration of HTL in plasma was found to be about $1.4 \%$ of plasma total homocysteine (28). It was also reported that incubation of radiolabeled HTL with human serum resulted in the disappearance of thiolactone, which was 25 fold faster than the rate of nonenzymatic hydrolysis of thiolactone (28). Further, it was shown that incubation of HTL with 
serum resulted in at least $50 \%$ of binding to be resistant to DTT indicating they were not linked to protein via disulfide linkage.

It has been more than a decade that the mechanisms of protein N-homocysteinylation have been proposed. Homocysteine thiolactone binds to $\varepsilon$-amino group of protein-lysine residues forming protein-Lys-N-homocysteine. It has also been proposed that during albumin-Nhomocysteinylation, cysteine attached to $\mathrm{Cys}^{34}$ of albumin binds to homocysteine attached to the lysine residue thereby forming a mixed disulfide at this lysine residue. However, the concentration of protein N-linked homocysteine is still a matter of debate, since the concentration of HTL is very low compared to homocysteine. Further, it is known that HTL is relatively unstable and can be hydrolysed to homocysteine. It is therefore surprising to note that most of the studies done to estimate the concentration of Protein N-linked homocysteine formed by HTL, did not assess the extent of S-homocysteinylation, although HTL could be hydrolyzed to homocysteine $(22,23,28,38-41)$. This led us to revisit the mechanism of binding of HTL to albumin.

It is known that commercially available HSA contains thiols bound to $\mathrm{Cys}^{34}$ and hence, we initially estimated the amounts of cysteine and homocysteine that is bound to $\mathrm{Cys}^{34}$ of albumin. The albumin, used in this study contained $0.32 \mathrm{~mol}$ of bound cysteine (albumin-Cys ${ }^{34}$-S-SCys)/mol of protein and $\sim 0.019$ of bound homocysteine (albumin-Cys ${ }^{34}$-S-S-Hcy)/mol of protein and is in agreement with previous reports (25). To ascertain, if hydrolysis of HTL results in the formation of albumin-Cys ${ }^{34}$ bound homocysteine (S-homocysteinylation) in addition to albumin-

This article is protected by copyright. All rights reserved. 
Lysine-N-homocysteinylation, we incubated $1 \mathrm{mM}$ HTL with $0.75 \mathrm{mM}$ HSA in $0.1 \mathrm{M}$ phosphate buffer $(\mathrm{pH}$ 7.4). Incubation of HTL with albumin resulted in the formation of albumin-Cys ${ }^{34}$ S-S-homocysteine (S-homocysteinylation). The formation of albumin-Cys ${ }^{34} \mathrm{~S}-\mathrm{S}$ homocysteine increased with time and after 24 hours of reaction 0.41 mol of albumin-Cys ${ }^{34} \mathrm{~S}-\mathrm{S}$ homocysteine per mol of albumin was formed (Figure 1A). This was lower than albumin-Cys ${ }^{34} \mathrm{~S}-$ S-homocysteine formed during the incubation of $1 \mathrm{mM}$ homocysteine with $0.75 \mathrm{mM}$ albumin (Figure 1A). After $3 \mathrm{~h}$ of reaction, approximately $0.34 \mathrm{~mol}$ of albumin-Cys ${ }^{34} \mathrm{~S}-\mathrm{S}$-homocysteine (mol/mol albumin) was formed, when $1 \mathrm{mM}$ of HTL was used, compared to $0.14 \mathrm{~mol}$ homocysteine/mol albumin formed during incubation of $1 \mathrm{mM}$ homocysteine with $0.75 \mathrm{mM}$ albumin. This is expected, since the concentration of homocysteine in solution available for Shomocysteinylation will be lower when $1 \mathrm{mM} \mathrm{HTL}$ is used. As mentioned earlier, in the first step of S-homocysteinylation, homocysteine binds to the cysteine attached to $\mathrm{Cys}^{34}$ forming homocysteine-cysteine mixed disulfide and albumin thiolate anion leading to a time dependent decrease in the concentration of cysteine bound to albumin-Cys ${ }^{34}$. Thus, if albumin-Cys ${ }^{34} \mathrm{~S}-\mathrm{S}-$ homocysteine is formed during the reaction of HTL with albumin, we would expect similar decrease in the cysteine concentration which was indeed observed (Figure 2B). Addition of 1 $\mathrm{mM}$ HTL to $0.75 \mathrm{mM}$ albumin, decreased the concentration of albumin bound cysteine (albumin-Cys ${ }^{34}$-S-S-Cys) from $0.33 \mathrm{~mol}$ cysteine/mol albumin to $0.21 \mathrm{~mol}$ cysteine/mol albumin, after $2 \mathrm{~h}$ of reaction (Figure 1B).

This article is protected by copyright. All rights reserved. 
Apart from albumin, there are several other proteins in plasma that could potentially bind to homocysteine and/or HTL. To ascertain, if binding of HTL with plasma also leads to Shomocysteinylation, we incubated $1 \mathrm{mM}$ HTL with plasma and determined the extent of proteinS-homocysteinylation. The formation of protein-S- homocysteine in plasma increased from 0.04 $\mathrm{mol} / \mathrm{mol}$ of protein to $0.13 \mathrm{~mol} / \mathrm{mol}$ of protein after an hour of reaction and equilibrium binding was achieved after $10 \mathrm{~h}$ of incubation (Figure 2A). At the same time, the amount of plasma protein bound cysteine decreased. Addition of $1 \mathrm{mM}$ HTL reduced the protein bound cysteine concentration from $0.35 \mathrm{~mol} / \mathrm{mol}$ of protein to $0.05 \mathrm{~mol} / \mathrm{mol}$ of protein after an hour of incubation. After this time point, the concentration of bound cysteine began to increase slightly until it reached equilibrium at $16 \mathrm{~h}$, where the final concentration of protein bound cysteine was $1.4 \mathrm{~mol} / \mathrm{mol}$ of protein (Figure 2B). HTL treated with human plasma protein revealed that the reaction was biphasic in nature; corroborating with the earlier study of homocysteine binding to human plasma protein (31). At the start of the reaction, there was a slow formation of protein$\mathrm{Cys}^{34}$-S-S-Hcy and after $1 \mathrm{~h}$ the formation of protein-Cys-S-S-Hcy increased rapidly till $16 \mathrm{~h}$, where it reached its equilibrium binding and then saturated.

All these results indicate that, homocysteine formed due to the hydrolysis of HTL, binds to the cysteine attached to $\mathrm{Cys}^{34}$ in the first step forming albumin thiolate anion and homocysteinecysteine mixed disulfide. Albumin thiolate anion thus formed in the first step then reacts with 
homocysteine-cysteine mixed disulfide and preferentially binds to homocysteine as has been shown earlier (25).

To further confirm that homocysteine binds to $\mathrm{Cys}^{34}$ of albumin, during the reaction of HTL with albumin, we performed mass spectral analysis. For this, native albumin or HTL treated albumin was digested with trypsin in $10 \mathrm{mM}$ ammonium bicarbonate buffer (enzyme substrate ratio, 1:25). The albumin bound fraction (16 or $24 \mathrm{~h}$ HTL treatment) was collected as mentioned above (see Materials and methods) and was digested with trypsin without reduction with DTT. In native albumin, the tryptic peptide [21-41] “ALVLIAFAQYLQQCPFEDHVK” (Uniprot KB ID: P02768, with a calculated monoisotopic mass: 2432.25 Da) contained unmodified Cys ${ }^{34}$. Binding of cysteine or homocysteine to $\mathrm{Cys}^{34}$ of this peptide would increase its mass to 2551.26 Da or $\quad 2565.276$

$\mathrm{Da}$, respectively

(Table

1).

In mass spectrum of this tryptic peptide obtained from native albumin, we observed peaks at $\mathrm{m} / \mathrm{z} 609.07(\mathrm{z}=+4)$ and $811.7(\mathrm{z}=+3)$ eluted at 48.167 min corresponding to native albumin (figure 3 A \& table 1, MS/MS spectra is shown in figure 3B and 3C) and $m / z 638.82(\mathrm{z}=+4)$, which corresponds to modification of $\mathrm{Cys}^{34}$ by cysteine eluted at $47.582 \mathrm{~min}$ (figure 4A \& table 1 , MS/MS spectra is shown in figure 4B). The change in retention time is observed for native peak and cysteine modified peak, which may be due to modification. However, homocysteine modified peptide [21-41] was not observed in the native albumin. Incubation of albumin with

This article is protected by copyright. All rights reserved. 
HTL for 16 hours resulted in the appearance of peaks at $m / z 642.33(z=+4)$ that corresponds to homocysteine modified tryptic peptide, indicating that incubation of albumin with HTL results in the formation of S-homocysteinylated albumin. This mass spectrum also contained the peak at $m / z$ 638.82, which is due to albumin-Cys ${ }^{34}$-S-S-Cys (Figure 4A and C \& Table 1). The sitespecific modification of the tryptic peptide "ALVLIAFAQYLQQCPFEDHVK", was confirmed from its LC-ESI- MS/MS spectrum of at RT: 47.61 min., which was acquired from QTOF 5600 (Figure 5). Theoretically calculated $m / z$ values of $b$ and $y$ ions from homocysteine modified tryptic peptide were compared with experimentally detected fragment ions' $\mathrm{m} / \mathrm{z}$ values and accordingly peaks were assigned (Figure 5A, MS/MS spectra is show in figure 5B-C). Thus, Shomocysteinylation of albumin-Cys ${ }^{34}$ can be confirmed, which is evident particularly from the peaks of $y$ - ion series: $y_{1}-y_{13}$, whose $m / z$ values clearly reveal the mass increment due to homocysteine modification of $\mathrm{Cys}^{34}$.

\section{$\mathrm{Cys}^{34}-\mathrm{SH}$ and N-homocysteinylation of albumin}

It has been reported earlier that HTL binds to albumin at the $\varepsilon$-amino group of lysine leading to the formation of albumin-Lys-N-Hcy-SH. Further, it was reported that there is a cross talk between cysteine attached to $\mathrm{Cys}^{34}$ of albumin and the homocysteine bound to the primary amine of lysine residues (23). This resulted in the formation of Albumin-Lys-N-Hcy-S-S-Cys, where the cysteine bound to homocysteine was believed to be the one attached to $\mathrm{Cys}^{34}$. However, from our results, it is clear that a large proportion of HTL is hydrolyzed to homocysteine, which

This article is protected by copyright. All rights reserved. 
causes S-homocysteinylation, whereby homocysteine binds to cysteine attached to Cys ${ }^{34}$ in the first step forming albumin thiolate anion and homocysteine-cysteine mixed disulfide. In the second step, albumin thiolate anion so formed preferentially binds to homocysteine of the mixed disulfide forming albumin-Cys ${ }^{34}$-S-S-Hcy and cysteine thiolate anion. We hypothesize that this free cysteine thiolate anion binds to homocysteine attached to $\varepsilon$-amino group of lysine and there is no cross talk between $\mathrm{Cys}^{34}$ and lysine residues.

To test this and to determine the amount of N-homocysteinylation of albumin in the presence of HTL, albumin thiolate anion (albumin-Cys ${ }^{34}-S^{-}$), formed after reduction of the thiols attached to $\mathrm{Cys}^{34}$ using DTT, was blocked by IAA. Under these circumstances, if there is a cross talk between $\mathrm{Cys}^{34}$ and lysine residues as reported earlier, then, it is expected that homocysteine attached to lysine would remain in reduced form (-SH). Addition of $1 \mathrm{mM}$ DTT to $1 \mathrm{mM}$ albumin for $1 \mathrm{~h}$. completely reduced all the thiols attached to Cys ${ }^{34}$ as determined by Ellman's reaction (Figure 6A). The albumin thiolate anion (free reduced thiol) was completely blocked using 55 mM IAA within 15 minutes (Figure 6B; see Methods section). DTT/IAA treated albumin (albumin-Cys ${ }^{34}$-S-IAA) was then treated with $1 \mathrm{mM}$ HTL to determine the amount of N-homocysteinylation and to see, if there is any cross talk between Cys ${ }^{34}$ and homocysteine bound to lysine (Schematic reaction 2). 
In this case, HTL can undergo only N-homocysteinylation, since albumin-Cys ${ }^{34}$-S is blocked, thereby preventing S-homocysteinylation. Further, the hypothesis that cysteine bound to Cys ${ }^{34}$ cross reacts with homocysteine bound to lysine cannot be operative here, as in this case Cys ${ }^{34}$ is blocked and it is expected that homocysteine bound to lysine will be in the reduced form (see Scheme 2, shown above). Addition of HTL to the DTT/IAA treated albumin resulted in formation of only $13 \mu \mathrm{M}$ (0.017 moles) of homocysteine/mole of albumin after 16 hours of reaction as determined by Ellman’s reaction (Figure 7A).

Interestingly, after $3 \mathrm{~h}$ of reaction with HTL no free thiol could be detected indicating that homocysteine attached to lysine was disulfide bound and no longer existed in the free reduced form. This could only be possible if thiolate anion of homocysteine (Hcy-SH), which was hydrolyzed from HTL, reacted with the lysine bound homocysteine forming albumin-Lys-NHcy-S-S-Hcy [(N-linked homocysteine bound S-homocysteinyl albumin moiety), (reaction 2)]. To investigate this, DTT/IAA treated albumin was incubated with $1 \mathrm{mM}$ HTL and $50 \mu \mathrm{l}$ aliquots were added to perchloric acid at different time intervals. The precipitated albumin was washed and then solubilized as mentioned in Materials and methods. The albumin solution was then treated with sodium borohydride to reduce any homocysteine bound to lysine bound homocysteine. Sodium borohydride treated albumin was further precipitated, washed and redissolved and the amount of reduced homocysteine bound to lysine was determined using Ellman's reagent (DTNB). After borohydride reduction we found that about 0.15 moles of 
homocysteine was bound per mole of albumin (Figure 7B) clearly indicating that homocysteine formed due to hydrolysis of HTL at physiological $\mathrm{pH}$ binds to the homocysteine that is bound to lysine. This clearly contradicts the hypothesis that cysteine or homocysteine bound to Cys ${ }^{34}$ cross talks with homocysteine bound to lysine.

\section{CONCLUSION}

Our study, thus, clearly reveals that S-homocysteinylation is the major modification that takes places in circulation during the reaction of HTL with plasma proteins and N-homocysteinylation is only a minor component. And also our study suggests that Hcy is in a very large excess of HTL in plasma but it questions the utlity of physiologically relevance of HTL in terms of human diseases such as cardiovascular disease.

\section{CONFLICT OF INTEREST}

None declared.

\section{AUTHOR CONTRIBUTIONS}

YS, TB and SS conceived and developed the methodology. YS performed experiments, data curation formal analysis and writing the original draft. SV and TB performed data curation, validation and writing, review editing of the manuscript. YS, AR and SV helped in visualization

This article is protected by copyright. All rights reserved. 
and writing, review editing of the manuscript. AZ, CC and SS conceptualized the project. SS supervised the project and editing of the manuscript.

\section{ACKNOWLEDGMENT}

We acknowledge the financial assistance from Council of Scientific and Industrial Research (CSIR), Ministry of Science and Technology, Govt of India, India under the XII FYP project titled “Centre for Cardiovascular and Metabolic Disease Research (BSC0122)”.

\section{References}

1. Eikelboom JW, Lonn E, Genest J, Jr., Hankey G, Yusuf S. Homocyst(e)ine and cardiovascular disease: a critical review of the epidemiologic evidence. Ann Intern Med. 1999;131(5):363-75. Epub 1999/09/04.

2. Mills JL, McPartlin JM, Kirke PN, Lee YJ, Conley MR, Weir DG, et al. Homocysteine metabolism in pregnancies complicated by neural-tube defects. Lancet. 1995;345(8943):149-51. Epub 1995/01/21.

3. Regland B, Johansson BV, Grenfeldt B, Hjelmgren LT, Medhus M. Homocysteinemia is a common feature of schizophrenia. J Neural Transm Gen Sect. 1995;100(2):165-9. Epub 1995/01/01.

This article is protected by copyright. All rights reserved. 
4. Perry IJ, Refsum H, Morris RW, Ebrahim SB, Ueland PM, Shaper AG. Prospective study of serum total homocysteine concentration and risk of stroke in middle-aged British men. Lancet. 1995;346(8987):1395-8. Epub 1995/11/25.

5. de Vries JI, Dekker GA, Huijgens PC, Jakobs C, Blomberg BM, van Geijn HP. Hyperhomocysteinaemia and protein S deficiency in complicated pregnancies. Br J Obstet Gynaecol. 1997;104(11):1248-54. Epub 1997/12/31.

6. Meigs JB, Jacques PF, Selhub J, Singer DE, Nathan DM, Rifai N, et al. Fasting plasma homocysteine levels in the insulin resistance syndrome: the Framingham offspring study.

Diabetes Care. 2001;24(8):1403-10. Epub 2001/07/27.

7. Seshadri S, Beiser A, Selhub J, Jacques PF, Rosenberg IH, D'Agostino RB, et al. Plasma homocysteine as a risk factor for dementia and Alzheimer's disease. N Engl J Med. 2002;346(7):476-83. Epub 2002/02/15.

8. Kang SS, Wong PW, Becker N. Protein-bound homocyst(e)ine in normal subjects and in patients with homocystinuria. Pediatr Res. 1979;13(10):1141-3. Epub 1979/10/01.

9. Kang SS, Wong PW, Curley K. The effect of D-penicillamine on protein-bound homocyst(e)ine in homocystinurics. Pediatr Res. 1982;16(5):370-2. Epub 1982/05/01.

10. Mansoor MA, Ueland PM, Aarsland A, Svardal AM. Redox status and protein binding of plasma homocysteine and other aminothiols in patients with homocystinuria. Metabolism. 1993;42(11):1481-5. Epub 1993/11/01.

This article is protected by copyright. All rights reserved. 
11. Wiley VC, Dudman NP, Wilcken DE. Interrelations between plasma free and proteinbound homocysteine and cysteine in homocystinuria. Metabolism. 1988;37(2):191-5. Epub 1988/02/01.

12. Wiley VC, Dudman NP, Wilcken DE. Free and protein-bound homocysteine and cysteine in cystathionine beta-synthase deficiency: interrelations during short- and long-term changes in plasma concentrations. Metabolism. 1989;38(8):734-9. Epub 1989/08/01.

13. Kang SS, Wong PW, Bidani A, Milanez S. Plasma protein-bound homocyst(e)ine in patients requiring chronic haemodialysis. Clin Sci (Lond). 1983;65(3):335-6. Epub 1983/09/01.

14. Smolin LA, Laidlaw SA, Kopple JD. Altered plasma free and protein-bound sulfur amino acid levels in patients undergoing maintenance hemodialysis. Am J Clin Nutr. 1987;45(4):73743. Epub 1987/04/01.

15. Guttormsen AB, Ueland PM, Svarstad E, Refsum H. Kinetic basis of hyperhomocysteinemia in patients with chronic renal failure. Kidney Int. 1997;52(2):495-502. Epub 1997/08/01.

16. Mansoor MA, Ueland PM, Svardal AM. Redox status and protein binding of plasma homocysteine and other aminothiols in patients with hyperhomocysteinemia due to cobalamin deficiency. Am J Clin Nutr. 1994;59(3):631-5. Epub 1994/03/01.

17. Mansoor MA, Bergmark C, Svardal AM, Lonning PE, Ueland PM. Redox status and protein binding of plasma homocysteine and other aminothiols in patients with early-onset

This article is protected by copyright. All rights reserved. 
peripheral vascular disease. Homocysteine and peripheral vascular disease. Arterioscler Thromb Vasc Biol. 1995;15(2):232-40. Epub 1995/02/01.

18. Andersson A, Lindgren A, Hultberg B. Effect of thiol oxidation and thiol export from erythrocytes on determination of redox status of homocysteine and other thiols in plasma from healthy subjects and patients with cerebral infarction. Clin Chem. 1995;41(3):361-6. Epub 1995/03/01.

19. Kang SS, Wong PW, Cook HY, Norusis M, Messer JV. Protein-bound homocyst(e)ine. A possible risk factor for coronary artery disease. J Clin Invest. 1986;77(5):1482-6. Epub 1986/05/01.

20. Jakubowski H, Goldman E. Synthesis of homocysteine thiolactone by methionyl-tRNA synthetase in cultured mammalian cells. FEBS Lett. 1993;317(3):237-40. Epub 1993/02/15.

21. Jakubowski H. Homocysteine thiolactone: metabolic origin and protein homocysteinylation in humans. J Nutr. 2000;130(2S Suppl):377S-81S. Epub 2000/03/18. 22. Jakubowski H. Protein homocysteinylation: possible mechanism underlying pathological consequences of elevated homocysteine levels. FASEB J. 1999;13(15):2277-83. Epub 1999/12/14.

23. Glowacki R, Jakubowski H. Cross-talk between Cys34 and lysine residues in human serum albumin revealed by N-homocysteinylation. J Biol Chem. 2004;279(12):10864-71. Epub 2004/01/01.

This article is protected by copyright. All rights reserved. 
24. Sengupta S, Chen H, Togawa T, DiBello PM, Majors AK, Budy B, et al. Albumin thiolate anion is an intermediate in the formation of albumin-S-S-homocysteine. $\mathrm{J}$ Biol Chem. 2001;276(32):30111-7. Epub 2001/05/24.

25. Sengupta S, Wehbe C, Majors AK, Ketterer ME, DiBello PM, Jacobsen DW. Relative roles of albumin and ceruloplasmin in the formation of homocystine, homocysteine-cysteinemixed disulfide, and cystine in circulation. J Biol Chem. 2001;276(50):46896-904. Epub 2001/10/11.

26. Curry S, Mandelkow H, Brick P, Franks N. Crystal structure of human serum albumin complexed with fatty acid reveals an asymmetric distribution of binding sites. Nat Struct Biol. 1998;5(9):827-35. Epub 1998/09/10.

27. Peters Jr T. All about albumin: biochemistry, genetics, and medical applications: Academic press; 1995.

28. Jakubowski H. Translational accuracy of aminoacyl-tRNA synthetases: implications for atherosclerosis. J Nutr. 2001;131(11):2983S-7S. Epub 2001/11/06.

29. Garel J, Tawfik DS. Mechanism of hydrolysis and aminolysis of homocysteine thiolactone. Chemistry. 2006;12(15):4144-52. Epub 2006/02/03.

30. Jacobsen DW, Gatautis VJ, Green R, Robinson K, Savon SR, Secic M, et al. Rapid HPLC determination of total homocysteine and other thiols in serum and plasma: sex differences and correlation with cobalamin and folate concentrations in healthy subjects. Clin Chem. 1994;40(6):873-81. Epub 1994/06/01.

This article is protected by copyright. All rights reserved. 
31. Togawa T, Sengupta S, Chen H, Robinson K, Nonevski I, Majors AK, et al. Mechanisms for the formation of protein-bound homocysteine in human plasma. Biochem Biophys Res Commun. 2000;277(3):668-74. Epub 2000/11/04.

32. Sogami M, Nagoka S, Era S, Honda M, Noguchi K. Resolution of human mercapt- and nonmercaptalbumin by high-performance liquid chromatography. Int J Pept Protein Res. 1984;24(2):96-103. Epub 1984/08/01.

33. Ellman GL. Tissue sulfhydryl groups. Arch Biochem Biophys. 1959;82(1):70-7. Epub 1959/05/01.

34. Jagannath S, Sabareesh V. Peptide Fragment Ion Analyser (PFIA): a simple and versatile tool for the interpretation of tandem mass spectrometric data and de novo sequencing of peptides. Rapid Commun Mass Spectrom. 2007;21(18):3033-8. Epub 2007/08/21.

35. Majors AK, Sengupta S, Willard B, Kinter MT, Pyeritz RE, Jacobsen DW. Homocysteine binds to human plasma fibronectin and inhibits its interaction with fibrin. Arterioscler Thromb Vasc Biol. 2002;22(8):1354-9. Epub 2002/08/13.

36. Sundaramoorthy E, Maiti S, Brahmachari SK, Sengupta S. Predicting protein homocysteinylation targets based on dihedral strain energy and pKa of cysteines. Proteins. 2008;71(3):1475-83. Epub 2007/12/14.

37. Silla Y, Sundaramoorthy E, Talwar P, Sengupta S. S-linked protein homocysteinylation: identifying targets based on structural, physicochemical and protein-protein interactions of homocysteinylated proteins. Amino Acids. 2013;44(5):1307-16. Epub 2013/02/13.

This article is protected by copyright. All rights reserved. 
38. Sikora M, Marczak L, Twardowski T, Stobiecki M, Jakubowski H. Direct monitoring of albumin lysine-525 N-homocysteinylation in human serum by liquid chromatography/mass spectrometry. Anal Biochem. 2010;405(1):132-4. Epub 2010/07/28.

39. Marczak L, Sikora M, Stobiecki M, Jakubowski H. Analysis of site-specific Nhomocysteinylation of human serum albumin in vitro and in vivo using MALDI-ToF and LCMS/MS mass spectrometry. J Proteomics. 2011;74(7):967-74. Epub 2011/02/19.

40. Stroylova YY, Zimny J, Yousefi R, Chobert JM, Jakubowski H, Muronetz VI, et al. Aggregation and structural changes of alpha(S1)-, beta- and kappa-caseins induced by homocysteinylation. Biochim Biophys Acta. 2011;1814(10):1234-45. Epub 2011/06/22. 41. Glowacki R, Bald E, Jakubowski H. An on-column derivatization method for the determination of homocysteine-thiolactone and protein N-linked homocysteine. Amino Acids. 2011;41(1):187-94. Epub 2010/03/06.

This article is protected by copyright. All rights reserved. 


\section{Tables and Figures legend:}

Table 1: Theoretically calculated intact molecular mass and $\mathrm{m} / \mathrm{z}$ of multiply protonated molecular ions that can be anticipated in the ESI mass spectrum corresponding to unmodified, cysteine modified and homocysteine modified peptide: ALVLIAFAQYLQQCPFEDHVK, which is [21-41] of HSA (Uniprot KB ID: P02768).

Figure 1: Binding of HTL with human serum albumin through disulfide (-S-S-) linkage. A) Formation of protein bound homocysteine (A) and decrease in bound cysteine (B) during incubation of $1 \mathrm{mM}$ HTL with human serum albumin $(0.75 \mathrm{mM})$ in $0.1 \mathrm{M}$ sodium phosphate buffer at physiological $\mathrm{pH}$ (pH-7.4). All the experiments were performed in triplicates.

Figure 2: Binding of HTL with plasma protein through disulfide (-S-S-) linkage. A) Formation of protein bound homocysteine B) amount of bound cysteine during incubation of $1 \mathrm{mM} \mathrm{HTL}$ with human Plasma (1ml diluted in 1:1 in buffer). All the experiments were done in triplicates.

Figure 3: (A)LC-ESI-MS Spectra of tryptic peptide of native HSA (750 $\mu \mathrm{M})$ is shown . The LC-ESI-MS spectra of native albumin peaks (609.07 and 811.7 Da) is shown (B) And (C) LCESI-MS/MS spectrum of precursor ion $609.07(\mathrm{z}=4)$ and $811.7(\mathrm{z}=3)$ of native albumin peptide with $b$ and $y$ ions is shown. $b$ and $y$ ions that matched with the theoretically generated list of 
peptides are shown in green. (D) LC-ESI-MS spectrum of bound cysteine (Albumin-Cys ${ }^{34}$-S-SCys) (638.8 Da, $\mathrm{z}=4$ ) precursor ion were represented with black arrow. (E) LC-ESI-MS/MS spectrum of precursor ion $m / z 638.8$ with $b$ and $y$ ions is shown. $b$ and $y$ ions that matched with the theoretically generated list of peptides are shown in green.

Figure 4: A) LC-ESI- MS Spectra of tryptic peptide of $16 \mathrm{~h}$ HTL (1 mM) treated HSA) is shown. The LC-ESI-MS spectra of bound cysteine (Albumin-Cys ${ }^{34}$-S-S-Cys, 638.8 Da) and bound homocysteine (Albumin-Cys ${ }^{34}$-S-S-Hcy, 642.3 Da) peptide mass were represented with black arrow respectively. B) LC-ESI-MS/MS spectrum of precursor ion $m / z 638.8$, which is $[\mathrm{M}+4 \mathrm{H}]^{4+}$ of Cys modified peptide (i.e Albumin-Cys ${ }^{34}$-S-S-Cys) with $b$ and $y$ ions is shown. $b$ and $y$ ions that matched with the theoretically generated list of peptides are shown in green. C) LC-ESI-MS/MS spectrum of precursor ion $\mathrm{m} / \mathrm{z}$ 642.3, which is $[\mathrm{M}+4 \mathrm{H}]^{4+}$ of Hcy modified peptide (i.e., Albumin-Cys ${ }^{34}$-S-S-Hcy) peptide with $b$ and $y$ ions is shown. $b$ and $y$ ions that matched with the theoretically generated list of peptides are shown in green.

Figure 5: Amount of free reduced thiol (albumin-Cys ${ }^{34}-\mathrm{SH}$ ) when $0.75 \mathrm{mM}$ albumin was treated with $1 \mathrm{mM}$ DTT at different time point, B) Free reduced thiols were completely blocked by 55 mM IAA and No free thiols were detected after 45 mins of incubation.

This article is protected by copyright. All rights reserved. 
Figure 6: N-homocysteinylation of albumin-Cys ${ }^{34}$-S-IAA. A) Lysine bound homocysteine mixed disulfide (Albumin-NH-Hcy-S-S-Hcy), B) Lysine bound homocysteine (Albumin-NHHcy-SH) during incubation of 1 mM HTL with DTT/IAA treated human serum albumin.

This article is protected by copyright. All rights reserved. 


\begin{tabular}{|c|c|c|c|c|}
\hline \multicolumn{5}{|c|}{21 ALVLIAFAQYLQQCPFEDHVK 41} \\
\hline & \multirow{2}{*}{$\begin{array}{l}\text { Intact } \\
\text { Molecular Mass } \\
\text { (calculated) }\end{array}$} & \multicolumn{3}{|c|}{$\mathrm{m} / \mathrm{z}$ (calculated) } \\
\hline & & $\begin{array}{l}{[\mathrm{M}+4 \mathrm{H}]^{4+}} \\
\mathbf{z}=+4\end{array}$ & $\begin{array}{l}{[\mathrm{M}+3 \mathrm{H}]^{3+}} \\
\mathbf{z}=+3\end{array}$ & $\begin{array}{l}\quad[\mathrm{M}+2 \mathrm{H}]^{2} \\
+ \\
\quad \mathbf{z}=+2\end{array}$ \\
\hline Unmodified & $2432.256 \mathrm{Da}$ & 609.072 & 811.760 & 1217.136 \\
\hline Cysteine modified & 2551.260 Da & 638.823 & 851.428 & 1276.638 \\
\hline $\begin{array}{l}\text { Homocysteine } \\
\text { modified }\end{array}$ & 2565.276 Da & 642.327 & 856.099 & 1283.646 \\
\hline
\end{tabular}

This article is protected by copyright. All rights reserved. 


\begin{tabular}{|c|c|c|c|c|}
\hline \multicolumn{5}{|c|}{21 ALVLIAFAQYLQQCPFEDHVK 41} \\
\hline & \multirow{2}{*}{$\begin{array}{l}\text { Intact } \\
\text { Molecular Mass } \\
\text { (calculated) }\end{array}$} & \multicolumn{3}{|c|}{$\mathrm{m} / \mathrm{z}$ (calculated) } \\
\hline & & $\begin{array}{l}{[\mathrm{M}+4 \mathrm{H}]^{4+}} \\
\mathbf{z}=+4\end{array}$ & $\begin{array}{l}{[\mathrm{M}+3 \mathrm{H}]^{3+}} \\
\mathbf{z}=+3\end{array}$ & $\begin{array}{l}\quad[\mathrm{M}+2 \mathrm{H}]^{2} \\
+ \\
\quad \mathbf{z}=+2\end{array}$ \\
\hline Unmodified & $2432.256 \mathrm{Da}$ & 609.072 & 811.760 & 1217.136 \\
\hline Cysteine modified & 2551.260 Da & 638.823 & 851.428 & 1276.638 \\
\hline $\begin{array}{l}\text { Homocysteine } \\
\text { modified }\end{array}$ & 2565.276 Da & 642.327 & 856.099 & 1283.646 \\
\hline
\end{tabular}

This article is protected by copyright. All rights reserved. 


\section{University Library}

\section{- M M N E R VA A gateway to Melbourne's research publications}

Minerva Access is the Institutional Repository of The University of Melbourne

Author/s:

Silla, Y;Varshney, S;Ray, A;Basak, T;Zinellu, A;Sabareesh, V;Carru, C;Sengupta, S

Title:

Hydrolysis of homocysteine thiolactone results in the formation of Protein-Cys-S-Shomocysteinylation

Date:

2019-08-01

Citation:

Silla, Y., Varshney, S., Ray, A., Basak, T., Zinellu, A., Sabareesh, V., Carru, C. \& Sengupta, S. (2019). Hydrolysis of homocysteine thiolactone results in the formation of Protein-Cys-S-Shomocysteinylation. Proteins: Structure, Function, and Bioinformatics, 87 (8), pp.625-634. https://doi.org/10.1002/prot.25681.

Persistent Link:

http://hdl.handle.net/11343/285750 